\title{
Task-Based Video Use for the Improvement of English Stress and Intonation
}

\section{Ebru Atak Damar}

ebruadamar@gmail.com

\section{Doi:10.5901/jesr.2014.v4n2p227}

\section{Abstract}

\begin{abstract}
The current study aims at examining the effects of videos on the development of English stress and intonation of first grade EFL learners in an ELT Department at a public university in Turkey. 44 EFL learners were participated in the study on the voluntary basis. 24 learners, who are assigned as the test group, were given a list of videos and an online tutoring program and related assignments as a supplement to a 3-hour Listening and Pronunciation course each week. 20 learners, the participants of the control group, were requested to attend only the classes and do the regular assignments. The study conducted through eleven weeks during the fall semester at the department. The total number of the hours that all the participants attended the course was 33. As for the test group, the studying hours, including the class hours, was calculated as approximately 110 hours during the term. The participants' development in spoken English was compared with the control group. Comparison was realized through two ways. First, the participants were pre-and post-tested by two experienced raters of pronunciation. Then they were given a questionnaire to investigate their pronunciation learning experiences and attitudes towards the development of pronunciation through videos (featured films, short films etc.) and the online program. The findings of the study indicate that videos were much more effective in improving the EFL learners' ability to produce and perceive different stress and intonation patterns in words, phrases and sentences than through the online tutoring programs. The findings also reveal that the students feel more comfortable themselves in a self-study for the improvement of intonation and stress in English.
\end{abstract}

\section{Introduction}

A number of resources on ESL/EFL pronunciation promote teaching nonnative speakers (NNSs) suprasegmentals to improve the intelligibility of their speech. Thus, that suprasegmentals play a crucial role in communication and proper intonation provides a high percentage of speech intelligibility. As language learners, we may expose a native speaker (NS) speaking English with perfectly intelligible consonants and vowels and with standard grammatical forms; and yet we may have the greatest of difficulty in understanding because the intonational patterns were entirely unnatural and strange to us and completely misinterpret the person's speaking. Related research show us that 'giving priority to the suprasegmental aspects of English not only improves learners' comprehensibility but is also less frustrating for students because greater change can be effected" (Mecnerney and Mendelson, 1992: p.120). Similarly, Morley (1991), Brown (1995), Clennell (1996), and Celce-Murcia, Brinton, and Goodwin (1996) provide theoretical evidence about pronunciation instruction. Although these resources base their statements on a theoretical understanding of prosody in discourse, they offer little, empirical evidence to support their claims about how suprasegmentals affect the intelligibility of nonnative speech. A close look to related research shows that either there have been very few studies so far which test the effectiveness of computer-assisted pronunciation training or the studies which provide empirical evidence about the use of videos in language classroom mostly focus on the development of reading and listening skills other than pronunciation (Seferoğlu, 2005; Garza, 2008). Therefore, the teaching aspect of pronunciation, including stress and intonation has frequently fallen behind that of the four basic skills in English. The importance of the issue is apparent that phonological competence is also one of the sub-categories of linguistic competence which is seen as a pre-requisite for language mastery according to Common European Framework of Reference (CEFR) for languages (Council of Europe, 2011). In other words, an EFL teacher is supposed to be able to help herself and her students respectively with both the perception and production of the target sounds and sound system. However, especially in teacher education, pronunciation training seems to be one of the neglected area among the competency development of teacher trainees

Therefore, the current study aims at investigating the development of English word stress patterns and intonation of EFL learners- junior ELT trainees- through videos. The significance of the study could be handled in a triangulative manner. One is related to its empirical nature since the field is lacking empirical evidence to support the importance of pronunciation instruction. Secondly, the participants of the study hold the great importance since they are teacher trainees who would be unique sources of the target language in a NNS environment. As a third consideration, the 
research design of the current study is partly action research which is mostly neglected type of research in teacher education studies.

The research questions of the study as follows:

1. Are videos effective in improving the pronunciation skills, namely intonation and stress, of EFL learners?

2. How does the videos help improve the pronunciation skills of EFL learners?

3. How do the students feel about the improvement (or not) of their pronunciation?

4. Does the students' pronunciation improve after using the videos?

5. Does the students' pronunciation improve after using the online tutoring program?

6. Is there any difference between the groups (who watch videos and who do not) in their development of pronunciation skills?

\section{Literature Review}

Among suprasegmental features, intonation and stress are the crucial elements for language acquisition and learning. In the related domain, 'intonation' is defined as the variation of pitch when speaking, the 'music' of a language and the important element of a good accent. In other words, English has a number of intonation patterns which add conventionalized meanings to the utterance: statement, question, surprise, sarcasm and teasing. 'Stress' is also referred to as a relative emphasis that may be given to certain syllables in a word and the similar patterns of phonetic prominence inside syllables. In many languages, changing the stressed syllable can also change the meaning of a word; in English, it is also realized to change the types of words (i.e. noun-verb pairs). Besides the aforementioned linguistic definitions, with a sociolinguistic point of view, they are seen as a set of phonological features that "seem to be crucial as safeguards of mutual intelligibility in interlanguage talk" (Jenkins, 2002, p. 96).

In related research, it is clear that many non-native speakers of English from different linguistic backgrounds have difficulty mastering the intonation and stress in English (Pennington and Ellis, 2000, Jenkins 2000 and Jenkins 2002). They experience two major problems with intonation and stress: misplacing and putting them everywhere in spoken discourse. In both cases, the EFL learners violate the communicative procedures and misinterpret the message and are, thus, misinterpreted too. Since such suprasegmentals play a crucial role in communication, their instruction should be involved in almost all educational curriculum of EFL settings. When we examined the related research, especially psycholinguistic literature, we show that NNSs frequently violate the appropriate use of intonation and stress in the target language and this affect the processing and comprehension of the listener. This also causes the NSs negative evaluations as stated in Pennington (1994, p.8): "... as a basis for deciding which features to teach, research is needed to identify those phonological features to which native listeners attend most and react most strongly".

In order to become competent in these phonological features, there are many ways of instruction (Levis and Grant, 2003). These are ranged from self-study and teacher instruction to the use of audios/videos and online tutoring programs. As well known, using videos in the classroom is widely recognized as an important resource for language teaching. Garza (2008) draws our attention to increasing number of foreign language programs beginning to integrate video materials into their curricula to optimize the student's comprehension of several features of the target language. In the literature, there is also a consensus that videos are more intrinsically motivating than audios made for EFL/ESL teaching since they embody the notion that "a film with a story that wants to be told rather than a lesson that needs to be taught" (Ward \& Lepeintre, 1996, p.28). Stempleski (2000) states that the realism of movies provides a wealth of contextualized linguistic, paralinguistic and authentic cross-cultural information, classroom listening comprehension and fluency practice. Through films, using longer pieces of discourse to allow students to practice stress and intonation is also beneficial, since most pronunciation books provide short, limited contexts for practicing the suprasegmental features. As a consequence, videos provide opportunity of being exposed to different native speaker voices, slang, reduced speeches, stress, accents, and dialects and they offer endless opportunities for pedagogically sound activities for developing fluency.

\section{Method}

The present study, basically a qualitative case study, adopted an action research approach. Action research which is systematic enquiry done by teachers (or other individuals in the teaching/learning environment) to gather information about-and subsequently improve-how they teach, and how well their students learn (Mills, 2003). Recently, action research, which is mostly used in basic EFL classes, has gained popularity in the field of teacher education. Over time, 
traditional teacher education, which did not emphasize student-centered classrooms, started to lose its value and something was felt to be missing. Burns (2005) notes that educational development is to do with the intention of improving the instructor's classroom practice. It is also added that carrying out an action research project contributes much to a lecturer's understanding of her students' and their achievement as a result of changing his/her conceptions of teaching. This change is defined as "a change essential for sustained pedagogical development" (p.58). This study also hold a task based language learning approach (TBLL) since the learners are given tasks to complete upon the videos they watched (Pica, Kang, and Sauro, 2006). As mentioned earlier, videos may yield other types of activities and actions that can be incorporated into the classroom setting, here TBLL is integrated with the use of movies for more beneficial practices in the language classroom. While carrying out this action research study, the researcher employed pre-tests and post-tests, semi-structured interviews, open-ended questionnaires, diaries and observation techniques to monitor the outcomes and evaluate the leaners' progress. Based on Hashemi's (2012) study reflecting on mixing methods in applied linguistic research, the current research attemps to employ “....'concurrent embedded design' (QUAL data are collected within the QUAN design, between pretests and posttests, and interpretations are based on...QUAL data)" (p.207).

\section{Participants}

After randomly selecting the participants from the population, a pre-test data elicited from all the subjects in the study before assigning them to groups. This step allowed the researcher to make sure that learners in the groups are at roughly the same level of language development to begin with. $44 \mathrm{EFL}$ learners participated in the study on the voluntary basis. Their ages ranged from 19-24. 32 of them were female and 12 were male. They were at their first year at an ELT department in a Turkish state university. Forty four students were randomly divided into two groups. Of the participants, 20 learners, assigned as the participants of the control group, were requested to attend only the classes and do the regular assignments. 23 learners, who are assigned as the test group, were given a list of videos and online tutoring programs and related tasks as a supplement to a 3-hour Listening and Pronunciation course each week. One learner could not be involved in the study due to some personal reasons. As for the comparison, both of the groups participated in the pre-test and post-test process throughout the study. The informed consent form was taken from all of the participants for the ethical considerations of the study.

As for the researcher part, there were two more participants of the study: Phil and Arosa ${ }^{1}$. They were involved as outsiders for negotiation in the research process during two phases: the selection of videos as consultants and the data analysis section as raters. In the data analysis, the raters and the researcher analyzed the performances according to the checklist prepared beforehand. The checklists consisted of information related to the learners' performances on the intonation and stress patterns of words, phrases, sentences used in the given videos and tasks.

\section{Procedures}

As for the selection of videos, the researcher consulted two qualified EFL teachers, Phil and Arosa who are native speakers of English. Choosing the right film for a particular level of students is the prerequisite to make use of the merits of viewing the videos. Since then, mostly content films are selected both to motivate the learners and to be able to reflect on their real life situations (see Appendix A). While selecting the films, the edited and customized authentic videos were preferred as they consist of more appropriate suprasegmental features. The appropriateness of content and the comfort level of students were taken into account in the selection process. The comprehensibility is the other criterion of selection of the videos for the purposes of the current research. Because it is important to choose videos that balance dialog with a high degree of visual support, appropriate speech delivery, clear picture and sound, and standard accent. Moreover, the words, videos and films, were used interchangeably throughout the study as both address the focus of the study.

Before getting into video viewing and the task part, all of the participants involved in pre-test procedures. A perception task, a paragraph reading task and a talk task were administered both at the beginning and at the end of the course. In the perception task, the participants were given a series of underlined words in sentences and contextualized sentences, and asked to choose the common stress and intonation patterns in them. In the paragraph reading tasks, same contextualized sentences were used. As for talk task, the participants were asked to watch a video Love in the Past' and, in pairs, they were requested to discuss on what they had listened and video-record it. The video is chosen as it consists of different intonation and stress patterns produced by the characters in the film. For the video-recording, all

${ }_{2}^{2}$ The pseudonames of the raters as outsiders-with ethical considerations 
the equipments were provided by the researcher. The records were handed to the researcher in a DVD format and kept by her till the end of the data collection procedure. According to their performance on the pre-test, the participants were approximately placed in the same level. The procedures in this study were simplified and modified forms of those used by Kuo (2004). The modifications and changes were done according to the status of participants of the current study as they are adult learners in an EFL context.

After conducting the pre-test, the participants, who were in the test group, were then given a list of movies with additional series of tasks. In pairs, the participants were then asked to do the following:

1. Watch each film segment at least twice on the basis of the schedule given by the researcher and identify the difficulties experienced in relation to pronunciation features in the diaries.

2. Watch the last film on the schedule and act it out in pairs and video-record it and hand it to the instructor.

3. Use the online tutoring program ${ }^{2}$ where is needed. Completing the task procedures, the participants were given an open-ended questionnaire evaluating the process they were involved in. After then, 10 of the participants in the test group were interviewed. As for the analysis, first, following the content analysis of the responses to each given statement, the units of analysis emerged from the data were identified. Second, under those main categories, the researchers formed the sub-categories on the basis of the clusters of recurrent themes in the data.

\section{Findings and Discussion}

Many of the anxiety-provoking factors reported by the participants involved in similar studies appeared to be generated by various speaking activities normally encountered in a language class. With an effort to use videos as both a self study and a supplement to the given course, the study also attempts to overcome the anxiety level of EFL learners. Learners in EFL classes frequently report a feeling overwhelmed and anxious when speaking, perhaps due to either immature vocabulary and grammar or inadequate and immature pronunciation and, thus, these feelings result in failure. Therefore, the current study aims at improving the pronunciation skills of EFL learners in an anxiety-free way.

Throughout the study, all of the participants were gone through the tasks which are requested according to the groups they are involved in. The overall performance across the tasks produced between two groups of students were analyzed and reported (Table 1). Then, learners' attitudes towards intonation and stress learning through videos were analyzed.

\begin{tabular}{|c|c|c|c|c|}
\hline \multirow{2}{*}{\multicolumn{5}{|c|}{ Paragraph Reading }} \\
\hline & & & & \\
\hline Test Group & $70 \%$ & $61 \%$ & $57 \%$ & $63 \%$ \\
\hline \multicolumn{5}{|l|}{ Post-Test } \\
\hline Control Group & $75 \%$ & $70 \%$ & $65 \%$ & $70 \%$ \\
\hline Test Group & $87 \%$ & $78 \%$ & $78 \%$ & $81 \%$ \\
\hline
\end{tabular}

Table 1. Comparison of Overall Performance across the groups (Pre and Post Tests)

As can be clearly seen from Table 1, the average scores for the three tasks for the control group increased slightly from the pre-test to post-test, from 65 percent to 70 percent. On the other hand, the mean scores of the test group performance through the tasks considerably increased from 63 percent to 81 percent. In other words, the data of the questionnaire mean us that there are not a large amount of difference between the test group and experimental group in the pre-test. They seem to be approximately in the same level at the beginning of the treatment period. It also shows that the tasks limited to classroom assignments and the practice within the class hours seem not sufficient in improving the important components of language skills such as intonation and stress. On the other hand, as it seems always valid, much time devoted to language learning seems to be benefited in all aspects of it. It is especially significant where language learners should concentrate on the requirements of phonological competency. Moreover, the findings of the pos-test across the groups seem to be in line with the findings of the similar studies that search for the better ways of pronunciation instruction (Jenkins, 2002; Garza 2008, Chen, 2012). When individual analysis was applied across the tasks given to the participants as pre- and post-test procedures, it is clear that the learners in the experiment group have gained much progress in the 'talk' task (from 57 to 78 per cent). It may result from the fact that each film in the task file

${ }^{2}$ http://www. sounds.bl.uk 
has different examples of interaction from diverse contexts.

The results obtained from the questionnaire data also revealed that the participants in the test group believe the importance of using films as audio-visual materials while learning the suprasegmental features of the target language such as intonation and stress patterns. Unfortunately, the small size of the test group made it difficult to draw statistically significant conclusions. However, it seems to show how powerful the videos on the improvement of intonation and stress patterns which Chun (1998) diagnoses as the neglected areas on the way to communicative competence. Qualitatively, the interview data also support the findings of the post-test and the questionnaire. Throughout the interviews, participants assert the effectiveness of the use of films to enhance their pronunciation skills both in general and with specific emphasis to intonation and stress system in English. Anecdotes driven from the most striking interview data state that:

\footnotetext{
"...through the weeks... I realized my errors, the stress on the wrong place...the stress on suffixes precedes a long pause..I was terrible, however I did not know it..."

"...-ical, -ate, ion, for instance technological, I really say that as technological, in the wrong run...First, I realize it in the film 'Student Power', when I am comparing my pronunciation...now I have the ability to recognize different accents...[such as] a Bulgarian accent"

"I sound Turkish when I am speaking English...it is apparent in the video-recordings...in the last task...even not like my partners' intonation in the questions... at last I understood why I sound strange to my Erasmus-mate."
}

As it is stated earlier, suprasegmentals also contribute to sociolinguistic competence. Chun (1998) suggests that intonation contributes to our interpretations of utterances as polite or impolite and that it marks the role of the participants' relationships in a conversation. The findings from the questionnaire support this idea as follows:

\footnotetext{
"I had the opportunity to compare my speech at the beginning and at the end...it is really developed. Especially, when I ask a question, I really ask a question...not like a casual statement. Thereafter I am deliberately kind while I am requesting something in English"

"...years later in my English career [!], I feel how I sound to the NSs, ...sure they laugh at me when I use my Turkishlike intonation and stress inmy speech...the most powerful moment is too see how I can reach the limits of native-like speech...it is not hard at all, I am gonna continue... listen, diagnose and speak..."
}

Through self study, the films were advocated by the participants since they decrease the anxiety level and increase the level of motivation of NNSs in perception and production level (83\%; n.19). This finding is in line with the findings in Wörde's (2003) study where the researcher investigated the perspectives of students' foreign language anxiety. Interviewees draw our attention to the motivating quality of the videos by mentioning as:

\footnotetext{
"...films at home, it was amazing...no stress...there is stress but on words not on me..., no anxiety both while listening and speaking...I felt safe while producing the [suprasegmental] features..."

"...I feel frustrated when I speak in front of the audience... watching films and [performing] the tasks beforehand...later feeling safe and comfortable in classroom production."
}

When the students were asked about the effectiveness of the online tutoring programs, most of them (74\%; n.17) claim that they did not find it very useful but artificial when compared to films studied. They also indicate that films serve real and authentic language and consist of much more interaction in them, and thus motivating as it is in the studies of Clenel, 1996; Jenkins, 2002; Levis and Grant, 2003 and Garza, 2008. A few of the participants (26\%, n.6) found it very beneficial as long as studied regularly. When the individual results of these learners are examined, it is clearly seen that they've utilized the programs only once or twice during the term.

\section{Conclusion}

The current trends, as the standardization of English language, like 'English as a lingua franca' and 'English as an international language', compel the policy makers, material writers and accordingly EFL/ESL teachers to produce an environment for standard English. As for standard English that is understandable by everyone, teaching suprasegmental features would be one of the priorities of the language teaching curriculum. Studies similar to that of the current one exploring other linguistic variables such as intonation, word stress, and various segmental features would also help us to more fully understand internationalization of the language and be ready for its implementation. Such insights can enhance our understanding of prosodic features in English, help us set pedagogical priorities, and provide guidelines for helping teachers and other EFL/ESL learners achieve intercultural communicative competence in English. Thus, the 
learners, with global perspective, will have the chance to 'share' their messages without misinterpretations and communication failures in intercultural dialogues throughout the world. This could also provide them to embrace 'diversity' in international settings as both learners and language teachers.

Broadly speaking, pronunciation is not solely the only key to effectiveness of language perception and production. However, a broad perspective that acknowledges the various roles that pronunciation features play in providing meaning in discourse would enhance both the quality and the number of the studies, programs and materials in the related domain. The current study aimed at increasing the perception and production of pronunciation features through films in order to have a high degree of communicative competence by EFL teacher trainees. It also provided evidence that the use of videos in the form of controlled self-study contributes significantly to the development of intonation and stress patterns in English, and it strengthened the broadly stated claims in the pedagogical literature on ESL/EFL pronunciation. Consequently, "making the most of movies in language classrooms" should be adopted as a motto for teachers who defend the merits of films as a powerful tool for language acquisition. This motto also refers to the utilization of real life captures through films in the language classrooms. In other words, teachers need to make the most of learning opportunities by means of films to justify the use of edited and customized authentic films in combination with the kind of communicative and interactive tasks. Thus, those kind of interactive combinations which may work well in EFL classrooms seems to serve as a rationale for further relevant research.

Certainly, there would be number of limitations that need to be acknowledged and addressed regarding the present study. The basic limitation for the study is the number of the participants since they are not truly representative of the population of EFL students in Turkey and could not represent the actual picture of using films for better pronunciation although it is not an issue of generalizability. The other limitation of the study might be the time limitation that individual analysis of the participants takes longer time by the raters since it requires both watching and listening the extracts repeatedly. Therefore, individual in-depth analysis of the participants' improvements on the research issue and even the comments made by the raters as native speakers would be evaluated as the topic for further research.

\section{References}

Brown, A. (1995). Minimal pairs: Minimal importance? ELT Journal, 49(2), 169-175.

Burns, A. (2005). AR: An Evolving Paradigm. State of the Art Article. Cambridge University Press

Celce-Murcia, M., Brinton, D., \& Goodwin, J. (1996). Teaching pronunciation: A reference for teachers of English to speakers of other languages. Great Britain: Oxford University Press.

Chun, D. (1988). The neglected role of intonation in communicative competence and proficiency. The Modern Language Journal, 72(3), 295-302.

Clennell, C. (1996). Promoting the role of English prosody in a discourse-based approach to oral interaction. Prospect, 11(3), 17-28.

Council of Europe (2011). Common European Framework of Reference for Languages : Learning, Teaching, Assessment. Council of Europe.

Garza, J.T. (2008). Evaluating the Use of Captioned Video Materials in Advanced Foreign Language Learning. Foreign language Annals. 24 (3). 239-258.

Hashemi, M. (2012). Reflections on Mixing Methods in Applied Linguistics Research. Applied Linguistics. 33 (2). 206 - 212.

Jenkins, J. (2000). The phonology of English as an international language. Oxford: Oxford University Press.

Jenkins, J. (2002). A sociolinguistically based, empirically researched pronunciation syllabus for English as an international language. Applied Linguistics, 23(1), 83-103.

Kuo, F. J. (2004). The relationship between stress teaching and high or low achievers. Unpublished master's thesis, National Kaohsiung University, Taiwan. www.sharedfiles/doc.128947.

Levis, J., \& Grant, L. (2003). Integrating pronunciation into ESL/EFL classrooms. TESOL Journal, 12(2), 13-19.

McNerney, M., \& Mendelsohn, D. (1992). Suprasegmentals in the pronunciation class: Setting priorities. In P. Avery \& S. Ehrlich (Eds.), Teaching American English pronunciation (pp. 185-196). Oxford: Oxford University Press.

Mills, G. E. (2003). Action Research: A guide for the teacher researcher, 2nd ed. Columbus, Ohio: Merrill Prentice Hall.

Morley, J. (1991). The pronunciation component in teaching English to speakers of other languages. TESOL Quarterly, 25(3), 481-520.

Pennington, M. (1994). Recent research in L2 phonology: Implications for practice. In J. Morley (Ed.), Pronunciation pedagogy and theory: New views, new directions (pp. 64-91). Washington, DC: TESOL.

Pennington, M., \& Ellis, N. (2000). Cantonese speakers' memory for English sentences with prosodic cues. The Modern Language Journal, 84(3), 372-389.

Pica, Teresa, Kang, Hyun-Sook and Sauro, Shannon (2006). "Information gap tasks: Their multiple roles and contributions to interaction research methodology". Studies in Second Language Acquisition 2, 301-338.

Seferoğlu, S. S. (2005). A study on teaching competencies of teacher candidates. Proceedings of International Conference on Education (ICE-2005) 709-716. National University of Singapore, Singapore. 


\section{Appendix A}

Timetable: Films/videos Used in the Treatment Procedure

\begin{tabular}{|c|c|c|}
\hline Time & Videos & Focus Area (l: intonation; S: stress) \\
\hline $\begin{array}{c}1^{\text {st }} \\
\text { week }\end{array}$ & $\begin{array}{l}\text { 'Love in the Past' given by the researcher in a DVD format and } \\
\text { Video-recording }\end{array}$ & None \\
\hline $\begin{array}{c}2^{\text {nd }} \\
\text { week }\end{array}$ & http://learnenglish.britishcouncil.org/en/word-street/indoor-sports & $\begin{array}{l}\text { I: conventionalized meanings to the } \\
\text { utterance: fear, trial, surprise, } \\
\text { question and S }\end{array}$ \\
\hline $\begin{array}{c}3^{\text {rd }} \\
\text { week }\end{array}$ & $\begin{array}{l}\text { http://learnenglish.britishcouncil.org/en/big-city-small-world/series-1- } \\
\text { episode-1-meeting-friends }\end{array}$ & I \& S: words, idioms, questions \\
\hline $\begin{array}{c}4^{\text {th }} \\
\text { week }\end{array}$ & http://learnenglish.britishcouncil.org/en/film1 & I \& S: presentations \\
\hline $\begin{array}{c}5^{\text {th }} \\
\text { week }\end{array}$ & http://learnenglish.britishcouncil.org/en/film2 & I \& S: presentations \\
\hline $\begin{array}{c}6^{\text {th }} \\
\text { week }\end{array}$ & $\begin{array}{l}\text { http://learnenglish.britishcouncil.org/en/overcooked/election-breakfast } \\
\text { http://film-english.com/2012/11/28/a-thousand-words/ }\end{array}$ & $\begin{array}{l}\text { I \& S: daily language, high } \\
\text { frequency words and statements } \\
\text { about likes and dislikes }\end{array}$ \\
\hline $\begin{array}{c}7^{\text {th }} \\
\text { week }\end{array}$ & $\begin{array}{l}\text { http://learnenglish.britishcouncil.org/en/magazine-articles/student- } \\
\text { power }\end{array}$ & $\begin{array}{l}\text { I \& S: Extensive reading and } \\
\text { narratives }\end{array}$ \\
\hline $\begin{array}{c}8^{\text {th }} \\
\text { week }\end{array}$ & http://film-english.com/1328 & $\begin{array}{l}\text { S: advanced level vocabulary } \\
\text { check }\end{array}$ \\
\hline $\begin{array}{c}9^{\text {th }} \\
\text { week }\end{array}$ & $\begin{array}{l}\text { http://vimeo.com/24302498 } \\
\text { http://film-english.com/2012/09/26/the-pleasure-of/ }\end{array}$ & Priority in sounding I \& S \\
\hline $\begin{array}{c}10^{\text {th }} \\
\text { week }\end{array}$ & Video-recording & None \\
\hline
\end{tabular}

